\title{
The Bush Administrations AND SADDAM HUSSEIN
}


This page intentionally left blank 


\title{
The Bush Administrations AND SADDAM Hussein DeCiding on Conflict
}

\author{
Alex Roberto Hybel \\ AND \\ Justin Matthew Kaufman
}




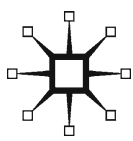

THE BUSH ADMINISTRATIONS AND SADDAM HUSSEIN

Copyright (C) Alex Roberto Hybel, 2006.

Softcover reprint of the hardcover 1st edition 2006 978-1-4039-7578-2

All rights reserved.

First published in hardcover in 2006 by PALGRAVE MACMILLAN ${ }^{\circledR}$ in the United States_a division of St. Martin's Press LLC, 175 Fifth Avenue, New York, NY 10010.

Where this book is distributed in the UK, Europe and the rest of the world, this is by Palgrave Macmillan, a division of Macmillan Publishers Limited, registered in England, company number 785998, of Houndmills, Basingstoke, Hampshire RG216XS.

Palgrave Macmillan is the global academic imprint of the above companies and has companies and representatives throughout the world.

Palgrave ${ }^{\circledR}$ and Macmillan ${ }^{\circledR}$ are registered trademarks in the United States, the United Kingdom, Europe and other countries.

ISBN 978-1-137-32092-6

ISBN 978-0-230-60114-7 (eBook)

DOI $10.1057 / 9780230601147$

The Library of Congress has cataloged the hardcover edition as follows:

Hybel, Alex Roberto

The Bush administrations and Saddam Hussein : deciding on conflict / by Alex Roberto Hybel and Matthew.

p. $\mathrm{cm}$.

Includes bibliographical references and index.

1. United States-Foreign relations-Iraq. 2. Iraq-Foreign relations_-United States. 3. United States_-Foreign relations-19894. United States-Military policy. 5. Bush, George, 1924-

6. Bush, George W. (George Walker), 1946- 7. Hussein, Saddam, 1937- 8. Persian Gulf War, 1991. 9. Iraq War, 2003- I. Title.

E183.8.157H93 2006

$956.7044^{\prime} 32-d c 22$

2006046013

A catalogue record of the book is available from the British Library.

Design by Newgen Imaging Systems (P) Ltd., Chennai, India.

First PALGRAVE MACMILLAN paperback edition: March 2013

1098876554321 
To

Barbara Peurifoy,

David, Karen, and Hanna Kaufman, and Jeremy Whyman 
This page intentionally left blank 


\section{CONTENTS}

Acknowledgments to the Second Edition ix

Foreword by Ronald Steel xiii

Preface to the Paperback Edition xvii

Introduction Two Surprises, Two Wars, Two Presidents, One Family 1

Chapter One Alternative Theories of Foreign Policy-Making

Chapter Two Two Harmful Surprises 19

Chapter Three The Logic of Surprise versus the Logic of Surprise Avoidance $\quad 47$

Chapter Four Two Very Different Wars 63

Chapter Five The Apple Sometimes Falls Close to the Tree 109

Chapter Six The Absence of a Rational Process 145

Chapter Seven Be Careful What You Hope For: The Consequences of Invading Iraq 155

$\begin{array}{ll}\text { Notes } & 177\end{array}$

Bibliography 205

$\begin{array}{ll}\text { Index } & 213\end{array}$ 
This page intentionally left blank 


\section{ACKNOWLEDgments TO THE SECOND EDITION}

My research informs my teaching, but it is through teaching that I often discern what I do not know. As a result, teaching has on more than one occasion dictated my research agenda. It is in the classroom that I am repeatedly rewarded by the discovery of students with tremendous intellectual capacity and energy, waiting to encounter someone who will take them seriously and provide them with the opportunity to excel. It was after being exposed to Justin Matthew Kaufman's work in one of my seminars that I realized that he was such a student. And that is how our research partnership started. Throughout the production of the first edition Justin was the novice; when we put together the second one, he was an equal partner.

Our work benefited from the research work and comments by a number of people. A few of them deserve special mention. Cassandra Lynn Waters, a Connecticut College alum, spent an entire semester looking into the foreign policy-making literature and summarizing some of the relevant findings. Stuart Vyse, Ronald Steel, William Rose, and the anonymous reviewers provided helpful suggestions. Students in my US Foreign Policy classes alerted me to a number of mistakes and inconsistencies in earlier drafts. They know who they are. Of no lesser value is Alexander L. George's contribution. Alex never read the manuscript, nor did he know that Justin and I were working on it; still, though some 29 years have gone by since he served as the director of my dissertation, his approach to the analysis of foreign policy-making remains deeply embedded in my mind. To all of them, many thanks. 
Many others deserve my gratitude for a number of reasons. The wisdom, affection, and kindness of my wife, Jan; the joyfulness of our two incredible daughters, Sabrina and Gabriela; the indulgent support of my in-laws, Barbara and Bob Peurifoy; and the unremitting love of my mother, Margarita, and her husband, Raymond Lonsbury, now both deceased, helped nurture my work.

One person deserves additional words of appreciation. Nearly three decades ago, while I was trying to complete my dissertation, my mother-in-law, Barbara Peurifoy, kindly volunteered to type it and edit it. Since then, no one has helped me more, or could have been more patient in my writing endeavor, than Barbara. Despite her tenacity, I continue to make mistakes, but I am their sole owner. I dedicate this book to her.

Alex Roberto Hybel STONINGTON, CT

One of my favorite songwriters once wrote of his success: "I find it hard to explain how I got here ... " Having my name attached to this book gives me a new appreciation of the utter humility that a man must feel when he sings that line in front of sold-out arenas and stadiums.

For as long as I can remember, I have been something of a dreamer. In school my teachers reported on this behavior to my parents with phrases like "he has so much potential," or "he clearly has good ideas"; phrases that were inevitably followed by the less-thanflattering "but his head always seems to be elsewhere." Of course my head was always elsewhere; it was drawing blueprints for my next big idea. I have always believed the greatest achievements/ideas are those that are original, unique, and progressive in content. By now I have realized that the process of arriving at such thoughts is often, at best, unavailing.

Nonetheless, in the course of my pursuits one person has seen my lofty goals and ideas as more than just extravagant dreams. In this forum I would like to simply recognize Alex Roberto Hybel. There 
are several good films that document the relationship between a student and a professor, such as Good Will Hunting, The Emperor's Club, and Dead Poets Society. Working with Alex while at Connecticut College and during the 18 months following my graduation felt nothing short of movie-like. Alex has been inspiring to me in the same way as Robin Williams's character (John Keating) was inspiring to his students in Dead Poets Society. In our regular meetings to discuss our respective responsibilities and the direction of this book, I had the rare opportunity to discuss any and every idea born in my mind with him and have the ideas listened to and scrutinized. In my academic experience, a relationship of this nature between a student and a professor is rare, and I am grateful to have been lucky enough to cross paths with Alex. Thus, as per my acknowledgment, I thank the most inspirational professor of my academic life, Alex Roberto Hybel, for giving me the tools to think critically about the world of politics and foreign policy-making, and the confidence to voice those thoughts. I hope our paths cross many times in the future.

When we published the first edition of this book in 2006, I was a recording artist with a keen interest in international relations. At the time, I regarded recording songs - my career-and writing about American foreign policy—my passion—as two wholly unrelated pursuits. Six years later, it is clear that the two could not be more intricately connected.

As we discuss in this edition, the decision to invade Iraq has had profound economic consequences for both the United States and the global economy in general. For nearly a decade, the Iraq War has diverted the attention of our leaders from matters of domestic import and siphoned more than $\$ 1$ trillion dollars from the nation's wallet.

Following the 2008 global financial crisis, I left my career in music, and I am now an aspiring attorney. It is possible-perhaps even probable-that I was never bound for a long and prosperous career in the music business. But two things are indisputable: millions of 
Americans, myself included, lost their jobs in the 2008 economic downturn, and the government spent nearly $\$ 1$ trillion between 2008 and 2009 alone to prevent the crisis from worsening.

While the Iraq War may not have directly caused the 2008 economic collapse, it at least exacerbated the effect of the crisis on the national deficit and, arguably, distracted our leaders from anticipating the impending domestic calamity. Indeed, America's foreign policy and America's national economy are inextricably linked. A bad decision with respect to one invariably bears consequences for the other. I believe the material we added in this edition stands for this proposition; that a war fought on the other side of the globe does not occur in an economic vacuum, and that our leaders must heed the lessons of wars past.

JUSTIN MATTHEW KaUfMAN NEW YoRK, NY 


\title{
FOREWORD
}

\author{
Ronald Steel
}

Should we expect the decision to go to war to be rational when so much else about human life is not? Of course we do expect this, and we are often disillusioned. This illuminating study of the two recent American wars in Iraq is a case in point. It asks why, and then demonstrates how; emotion rather than reason guided the decisions to go to war. In doing so it reminds us once again that even in the affairs of state, the heart has its reasons that reason does not know.

No activity of a state demands more of its citizens or evokes more fervent emotions than does war. Yet few are subject to less hard analysis by those who make the critical decisions. This distressing axiom is splendidly illustrated by Alex Hybel and Justin Kaufman. With precision and intellectual objectivity they demonstrate, on both a theoretical and a practical level, how emotion and wishful thinking supplanted rationality in the two Iraq wars.

War is, of course, always unpredictable, both in its course and in its consequences. For this reason those who embark upon it tread upon uncertain ground. They should be wary, but almost without exception the instigators of war are dramatically bold. They believe that they can control the consequences of their actions.

In defense of their bold actions they sometimes cite Clausewitz, who famously argued that war is the pursuit of politics by other means. But they do not take to heart the warning inherent in his famous dictum. If war is indeed the pursuit of politics, then it is obviously subject to all the irrationality, hyperbole, and dishonesty of the political arena. War is just as haphazard, unpredictable, and 
irrational as any other form of human behavior. History and literature are replete with examples.

Indeed it would be heroically difficult to prove the contrary. Yet such is our human proclivity to war-indeed our attraction to itthat we want to believe war occurs because the reasons for it are overwhelming and ineluctable-and even more, that the ultimate consequences can be known and controlled. If we did not naively believe this we might be less inclined to pursue it.

War is a staple of human behavior. It is doubtful that there has ever been a moment when it was not taking place somewhere or other on our planet. The scale varies according to the capacity of the participants. And the rationale depends on the usual factors of fear, greed, ambition, hate, opportunity, ignorance, and delusion, to name the most obvious.

In some cases wars seem to break out with stunning spontaneity, like powder kegs that apparently ignite on their own. But on closer inspection one notes that someone filled the powder kegs, or put them in a hazardous place, or inflated their importance. Powder kegs are often the pretext rather than the primary cause for war. Their significance usually lies not in the event itself, but rather in the reaction to it.

War is, by its very nature, never a one-sided affair. One side may initiate and the other side respond, but that is only the narrative part of the story. The more important question lies in why nations deliberately choose war and believe it will necessarily advance what they perceive to be their interests.

Some states are simply aggressive and seek continental or even global domination. This is an ambition that they usually describe in idealistic terms, such as "advancing civilization," "world order," and the like. More commonly, a state may launch a war for what its leaders assert to be "defensive" reasons.

Among these is the perceived need to attack before being attacked. While this is essentially an aggressive act, it is often justified by those who commit it as "preemption," or more vaguely as 
"preventive war." A particularly egregious example of this would be Nazi Germany's invasion of Poland and later of the Soviet Union.

The attacked nation may, indeed usually does, choose to respond in kind, and in this case a full-fledged war takes place. We then say that the nation being attacked is forced into fighting a defensive war. But of course not all nations respond to aggression by resisting their attacker. Some simply surrender.

That may be viewed as a cowardly reaction. It certainly is not considered to be heroic. But in some cases, of which history furnishes myriad examples, it may be deemed a practical way of dealing with overwhelming odds and making the best of a hopeless situation.

One variant for a weak state in the path of a powerful aggressor is to proclaim its neutrality and to be as unobtrusive and cooperative as possible. Such states in certain cases can be more useful to the aggressor as formal "neutrals" than as occupied territories. This was the path chosen by Sweden and Switzerland in World War II.

There is no all-purpose formula for explaining why nations launch aggressive wars or why they respond as they do to the threat (real, perceived, imagined, or manipulated) of aggression (actual, potential, or contrived) against them. This depends on the nature of the state, the psychology and ambitions of its leaders, and an assessment of the costs and benefits of going to war.

The human factor is clearly critical. Those in control of a statewhether elected, crowned, or self-appointed-make the decision between war and peace. The general assumption is they do so for reasons that appear to be rational to them, at least at the time. For its part the public, which in a democracy must theoretically approve the decision to go to war, has to be persuaded that its leaders are reacting rationally and in the public's general interest.

This is how it is supposed to work. But the burden of proof is greater on the elected leaders when the war is aggressive rather than defensive - that is to say, if it is a war of choice rather than a war of necessity, a war the nation launches rather than one it responds to. The war in Vietnam represents the former, World War II the latter. 
The former, largely because of its results, is regarded as embarrassing and even shameful, the latter is extolled as "the Good War."

Good wars inspire heroic stories; bad wars provoke a search for explanations. This book is a particularly thoughtful explanation of how emotion and ambition undermined rationality in the Iraq wars of the two George Bushs. The prose of these two authors is cool, their reasoning rigorous, and their conclusions both sobering and highly instructive. 


\section{Preface to the Paperback Edition}

The international environment and the United States' domestic political, economic, and social spheres have changed markedly since the start of the Iraq War in 2003 and since the publication of this book's first edition in 2006. Though it would be specious to claim that George W. Bush's decision to attempt to topple Saddam Hussein's regime and to replace it with a friendly democratic government was the sole cause of the changes that ensued, there is very litthe doubt that his choice engendered multiple negative effects. On the whole, what has resulted both in the United States and in the world arena during the past nine years reinforces a central claim at the end of our first edition. Namely, "that though complete rationality in foreign policy-making is humanly impossible, a substantial measure of rationality is greatly needed. The presence of rationality in an uncertain world cannot guarantee success, but its repeated absence courts disaster."

In our new chapter we revisit the claims made by members of George W. Bush's administration as they were formulating the Iraq war policy, assess the extent to which those assertions concurred or differed from the intelligence they relied on, and compare the prognosis they made with the realities they encountered following the implementation of their plans. Our postscript analysis not only validated our initial concerns but also compelled us to once again acknowledge that presidents cannot afford for a moment to disregard Carl von Clausewitz's warning that war "is the province of chance. In no other sphere of human activity must such a margin be left for this intruder. It increases the uncertainty of every circumstance and deranges the course of events." 
XVIII / PREFACE TO THE PAPERBACK EDITION

If war is the province of chance even when intelligence is abundant, what can one expect when information is disregarded or manipulated to serve the expectations or political ambitions of the policy designers? As we try to encapsulate in our last chapter, one can await the proliferation of exceedingly high human, political, social, economic, and security costs.

Alex Roberto Hybel, Stonington, CT Justin Matthew Kaufman, New York, NY 